\title{
Pemberdayaan Karang Taruna Satya Dharma Bhakti Desa Mainan Melalui Pembuatan dan Pemasaran Pot Tanaman Hias
}

\author{
Siti Lady Havivi' ${ }^{\text {, Budi Santoso }}{ }^{2}$, Nopriawan Mahriadi ${ }^{3}$ \\ 1,2,3Program Studi Ilmu Komunikasi Stisipol Candradimuka Palembang \\ email: siti.lady.havivi@ stisipolcandradimuka.ac.id, \\ budi_santoso@stisipolcandradimuka.ac.id, \\ Nopriawan.Mahriadi@stisipolcandradimuka.ac.id
}

\begin{abstract}
Abstrak
Kegiatan pemberdayaan masyarakat ini merupakan ejawantah peran perguruan tinggi dalam upaya untuk memampukan masyarakat Desa Mainan, Kecamatan Sembawa, Banyuasin melalui pemanfaatan dan optimalisasi potensi sosial, ekonomi, dan budaya yang dimiliki secara mandiri. Berdasarkan observasi dan diskusi terarah dengan pemangku kepentingan, mitra pengabdi yang ditunjuk adalalah Karang Taruna Satya Dharma Bhakti dengan kegiatan utama berupa pengembangan kewirausahaan pembuatan pot tanaman hias berbahan dasar kain atau ambal bekas. Pemilihan ini berdasarkan fakta bahwa saat ini tanaman hias menjadi kesukaan baru masyarakat Indonesia sehingga kebutuhan alat pendukung seperti pot semakin meningkat. Produk pos tanaman hias ini kemudian dipasarkan melalui media sosial Facebook, Instagram, dan twitter untuk memperluas jangkauan pemasaran dan kesadaran produk pembeli. Kegiatan pengabdian ini memberikan tambahan energi bagi pegiat kewirausahaan Karang Taruna Satya Dharma Bhakti karena mendapatkan pengetahuan untuk desain baru dan penjualan yang semakin menjanjikan.
\end{abstract}

Kata kunci : pemberdayaan, pot hias, pemasaran digital

\begin{abstract}
This community empowerment activity is a manifestation of higher education's effort to enable the people of Desa Mainan, Sembawa District, Banyuasin through the utilization and optimization of their own social, economic and cultural potential. Based on observations and focused group discussions with stakeholders, the designated service partner is Karang Taruna Satya Dharma Bhakti with the main activity of developing entrepreneurship in making ornamental potted plants made from used cloth or ambal. This selection is based on the fact that currently ornamental plants are the new hobby of Indonesians so that the need for supporting tools such as pots is increasing. These ornamental plant post products are then marketed through social media like Facebook, Instagram, and Twitter to raise product awareness of potential buyers. This empowerment activity provide additional energy for the entrepreneurial activists of Karang Taruna Satya Dharma Bhakti because they gain knowledge for new designs and increasingly promising sales.
\end{abstract}

Keywords: community empowerment, ornamental pot, digital marketing 


\section{Pendahuluan}

Pemberdayaan masyarakat adalah upaya untuk memampukan masyarakat dalam membangun sekaligus mengembangkan potensi yang dimiliki secara mandiri. Pemberdayaan yang demokratis dan partisipatoris akan memperhitungkan nilai-nilai intrinsik yang berlaku dalam masyarakat an sich. Ginanjar Kartasasmita, mantan kepala Bappenas RI mengatakan bahwa pembangunan yang bertumpu pada masyarakat (community-based development) mengandung nilai-nilai yang sejatinya berakar dari kearifan lokal (local wisdom), semisal gotong royong dan kekeluargaan (Kartasmita, 1997).

Selain dari nilai kearifan lokal, yang perlu menjadi titik perhatian lain adalah posisi masyarakat. Dalam pemberdayaan, masyarakat bukan objek atau penerima manfaat pasif (passive beneficiaries) semata melainkan sebagai subjek aktif yang dituntut untuk kreatif dan penuh inisiatif, dan ini merupakan esensi dari kegiatan pemberdayaan. Oleh sebab itu, menggalang partisipasi aktif masyarakat untuk secara mandiri mengatasi persoalan yang dihadapi secara bersama-sama, seperti yang dikatakan oleh Purbantara dan Mujianto (2019), adalah satu tujuan inti dari pemberdayaan masyarakat. Dengan demikian, masyarakat, tak terkecuali unsur-unsur yang ada di dalamnya (komunitas, organisasi pemuda, dll), adalah elemen penting dalam proses pembangunan untuk mencapai kedaulatan dan kesejateraan ekonomi yang dicitakan.

Elemen penting di luar masyarakat yang seyogyanya terlibat dalam proses pemberdayaan, selain pemerintah, adalah lembaga Perguruan Tinggi. Sutoro Eko (2002) mengatakan bahwa kerjasama yang melibatkan berbagai pihak, dari berbagai bidang kemampuan, akan membuat upaya pemberdayaan semakin efektif dan menyeluruh. Perguruan tinggi adalah institusi yang seyogyanya memiliki kemampuan teoretis berupa kajian, konsep, dan perencanaan yang butuh penerapan lapangan. Sejatinya perguruan tinggi yang membutuhkan masyarakat, karena menyediakan kesempatan untuk mempraktikkan pengetahuan yang dimiliki.

Sehubungan dengan ini, tim pengabdian masyarakat Stisipol Candradimuka berupaya untuk membumikan prinsip-prinsip pemberdayaan di atas dalam kegiatan pengabdian yang berlangsung selama bulan Desember 2020. Kegiatan ini merupakan satu rangkaian kuliah kerja nyata tematik di Desa Mainan, yang merupakan bagian dari Kecamatan Sembawa, Kabupaten Banyuasin, Provinsi Sumatra Selatan. Lokasi desa dengan luas kurang lebih $4.900 \mathrm{~m}^{2}$ ini cukup strategis karena berada di jalur alternatif menuju Kota Palembang dan juga menjadi tempat persinggahan (transit) bagi warga desa tetangga (Dusun Limau dan Desa Pulau Harapan) untuk menjual hasil kebun. Berdasarkan data, jumlah total penduduk Desa Mainan berjumlah 2.792 jiwa. Lebih dari 50\% penduduk usia produktif bekerja di sektor informal sebagai petani dan pedagang. Sedangkan 35\% dari jumlah populasi adalah penduduk berusia 20 - 38 tahun. Artinya, banyak penduduk yang masuk dalam kategori usia produktif.

Satu modal sosial penting yang dimiliki oleh Desa Mainan adalah keberadaan lembaga kepemudaan, yaitu Karang Taruna Satya Dharma Bhakti (KTSDB), dan 
Kelompok Wanita Tani (KWT) Teratai. Saat ini tercatat 30 orang pemuda tergabung sebagai anggota aktif KTSDB. Karang Taruna ini lumayan aktif menyelenggarakan kegiatan-kegiatan skala kecil meski dalam kondisi yang serba terbatas. Bersama dengan pemerintah desa dan KWT Teratai mereka menginisiasi Gerakan Tanam Sayur (Gertas) bagi rumah tangga sebagai satu upaya untuk memperkuat ketahanan pangan. Selain itu, KTSDB juga mempunyai kegiatan ekonomis berupa kewirausahaan mandiri. Namun, divisi ini belum berjalan sesuai harapan. Satu produk yang telah dihasilkan adalah pot tanaman hias berbahan dasar kain. Sayangnya, usaha yang dimulai pada pertengahan tahun 2020 ini kurang berjalan dengan baik dikarenakan keterbatasan desain, modal, dan bahan.

Karang Taruna Satya Dharma Bhakti memerlukan dukungan manajemen yang memadai dalam menghasilkan produk pot yang berkualitas sehingga memiliki nilai ekonomis. Terkait pula dengan hal tersebut, strategi pemasaran yang efektif sangat diperlukan guna meningkatkan permintaan pasar yang tidak hanya berasal dari kalangan masyarakat Desa Mainan tetapi dapat merambah ke wilayah kota bahkan luar kota. Saat ini, pemasaran pot tanaman hias hanya dilakukan secara sederhana yaitu melalui penjualan langsung di lapak pinggir jalan utama Desa. Sedangkan penjualan melalui Facebook juga sudah dilakukan namun belum optimal. Facebook adalah media yang saat ini sangat populer dengan marketplace dengan fasilitas facebook ads (Barokah dkk, 2021), namun kegiatan pemasaran produk atau layanan tidak cukup menggunakan satu platform saja, namun juga dapat melalui Instagram, Twitter, Youtube dan lainnya untuk mendapatkan hasil yang optimal (Wardhana, 2015). Media sosial digunakan sebagai alat komunikasi pemasaran untuk meningkatkan kesadaran calon pelanggan terhadap produk atau layanan, lalu meningkatkan imej atau citra, dan tujuan akhirnya dapat meningkatkan penjualan (Kotler dan Keller, 2016).

\section{Metode}

Kegiatan pengabdian ini dilakukan berdasarkan data yang diperoleh dari hasil pengamatan lapangan (observasi) dan dikusi kelompok terarah (Focus Group Discussion/FGD) dengan para pemangku kepentingan Desa Mainan, yaitu kepala desa beserta perangkatnya, pengurus Karang Taruna Satya Dharma Bhakti dan Kelompok Wanita Tani Teratai, serta perwakilan masyarakat. Hasil observasi dan FGD ini menjadi landasan bagi tim pengabdi dalam menyusun langkah atau tahapan kegiatan pengabdian. Berikut adalah tahapan yang dilakukan:

1. Melakukan observasi lapangan melalui kunjungan dan koordinasi dengan Kepala Desa Mainan terkait program pengabdian masyarakat pada sektor kewirausahaan mandiri. Sasaran yang diberikan adalah Karang Taruna Satya Dharma Bhakti.

2. Mengidentifikasi permasalahan dan menganalisa kebutuhan mitra. Lalu melakukan pemetaan terhadap program pengabdian masyarakat pada usaha pembuatan kerajinan tangan yang menggunakan barang bekas.

3. Pelaksanaan program pengabdian masyarakat pada sektor kewirausahaan mandiri: Serah terima bantuan kepada mitra Karang Taruna Satya Dharma Bhakti 
Desa Mainan dan pengarahan/sosialisasi terkait Kewirausahaan Mandiri yang fokus kepada pot tanaman hias.

4. Pelaksanaan program pengabdian masyarakat pada sektor kewirausahaan mandiri: Pengambilan gambar proses pembuatan pot tanaman hias untuk video dokumenter karang taruna yang akan dijadikan sebagai media promosi untuk dishare melalui media sosial.

5. Optimalisasi penggunaan media sosial sebagai media pemasaran digital untuk meningkatkan awareness masyarakat di luar Desa Mainan terhadap kegiatan pembuatan dan penjualan pot tanaman hias.

6. Melakukan evaluasi kegiatan sebagai pedoman perbaikan untuk kegiatan pengabdian selanjutnya.

\section{Hasil dan Pembahasan}

Kegiatan pengabdian difokuskan pada dua hal, yaitu (1) proses produksi pembuatan pot tanaman hias dan (2) pemasaran pot tanaman hias.

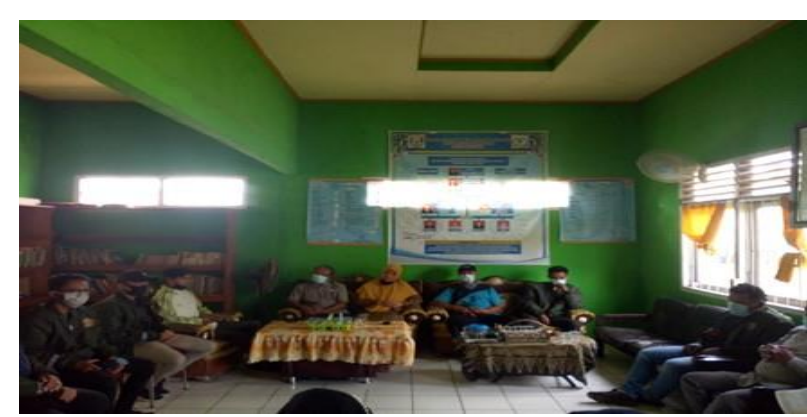

(a)

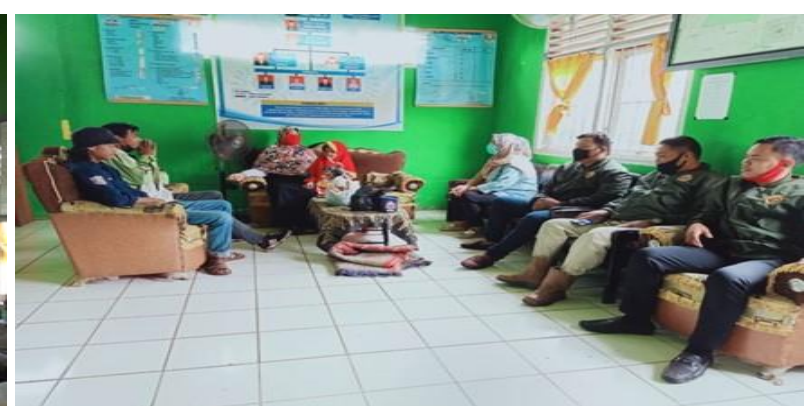

(b)

Gambar 1. Kegiatan (a) Observasi dan (b) FGD dengan pemangku kepentingan Desa Mainan

1. Proses pembuatan pot hias yang dilakukan oleh tim pengabdi bersama dengan anggota Karang Taruna ditampilkan dalam gambar-gambar di bawah ini:

a. Membuat pola ambal bekas, menggunting ambal menjadi beberapa bagian sesuai kebutuhan untuk digunakan sebagai kerangka awal pembentukan pot tanaman.

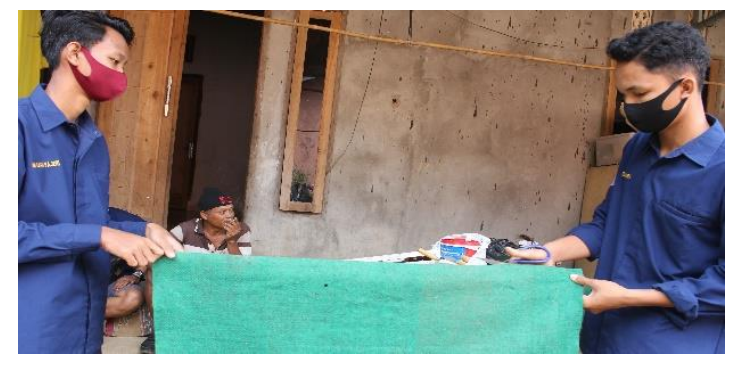

Gambar 2. Membentuk pola ambal 
b. Mencelupkan pola ambal ke dalam material semen cair agar pot lebih kuat, lalu dibentuk dengan menggunakan ember cat bekas yang dibalik dan digantung di kayu yang ditanam. Lalu, dikeringkan.

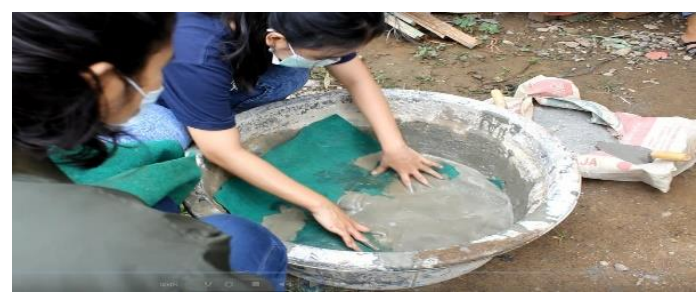

Gambar 3. Pencelupan pola ambal ke dalam semen

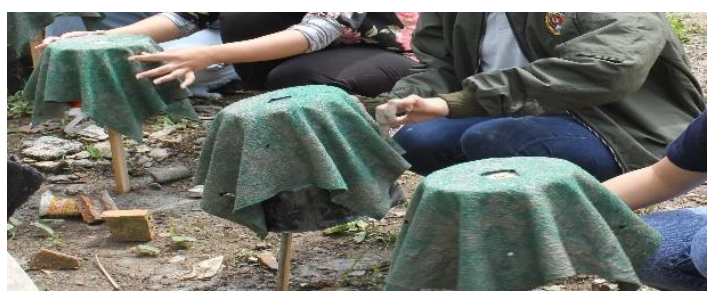

Gambar 4. Pembentukan pot sesuai keinginan

c. Setelah pola ambal dikeringkan selama satu hari, lalu menambahkan kembali material semen yang telah dicampur pasir pada pola yang sudah kering agar pot dapat menjadi lebih kuat saat digunakan.

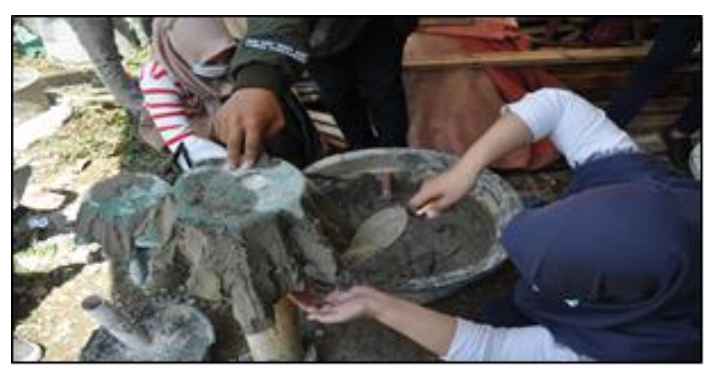

Gambar 5. Kerangka pot disemen kembali agar lebih kokoh

d. Setelah material semen kering kembali, tahap selanjutnya ialah pengecatan warna dasar yaitu memberi warna hitam pada pot.

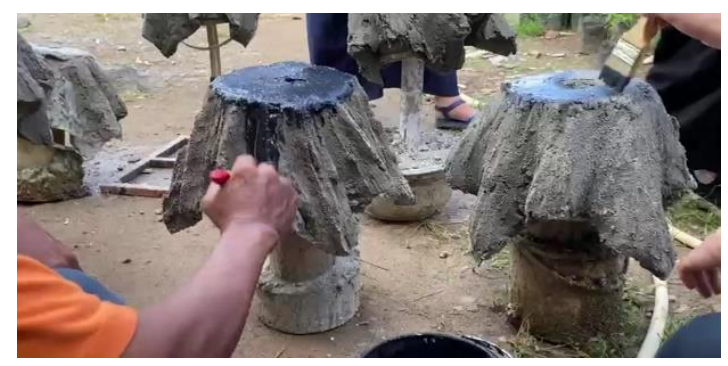

Gambar 6. Pengecatan warna dasar 1 
e. Pengecatan kembali dengan memberi warna dasar kuning sebagai warna dasar primer. Lalu terakhir, mencampurkan semua warna sesuai dengan nilai seni yang ingin ditampilkan.

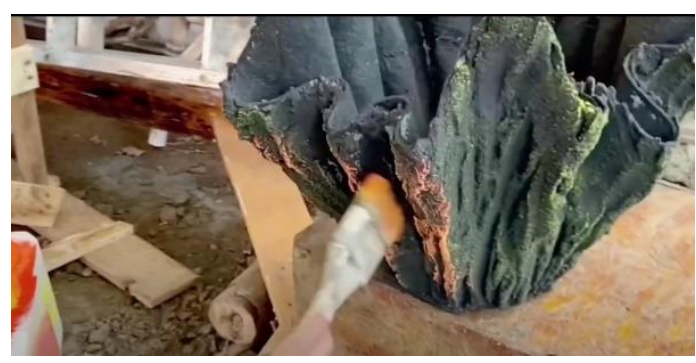

Gambar 7. Pengecatan warna dasar 2

f. Pengeringan cat, lalu pot tanaman hias dapat digunakan dan siap dipasarkan baik melalui media konvensional maupun media sosial.

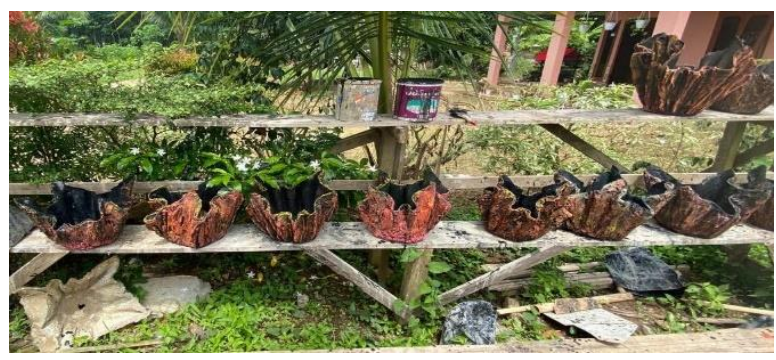

Gambar 8. Tanaman siap dipasarkan

2. Selama proses produksi pembuatan pot tanaman hias dilakukan, pengabdi juga melakukan pengambilan gambar proses tersebut untuk video dokumenter Karang Taruna yang akan dijadikan sebagai media promosi untuk di-share melalui media sosial. Setelah proses produksi selesai, dilanjutkan dengan tahap pemasaran produk yang fokus terhadap optimalisasi penggunaan media sosial sebagai media pemasaran digital.

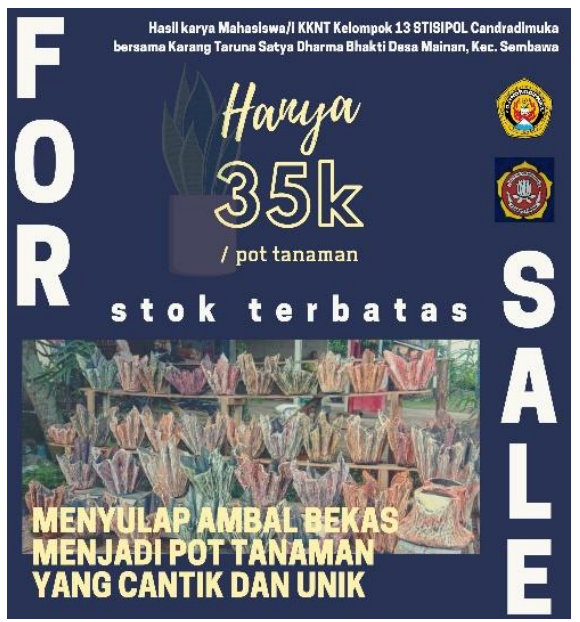

Gambar 9. Poster untuk promosi produk 
Kegiatan sosialisasi pemanfaatan media sosial sebagai digital marketing dilakukan dengan mengacu pada aktivitas pemasaran melalui jejaring sosial. Kautsarina (2013) membuat beberapa tahapan yang lazim dilakukan untuk memasarkan produk melalui media digital, yaitu:

Tabel 1. Aktivitas Pemasaran Produk

\begin{tabular}{|c|l|}
\hline No. & \multicolumn{1}{|c|}{ Tahapan } \\
\hline 1 & Mengunggah foto produk \\
\hline 2 & Menulis status tentang produk yang ditawarkan \\
\hline 3 & Memberi tag foto produk kepada calon konsumen \\
\hline 4 & Membuat fan page \\
\hline 5 & Menulis tinjauan produk \\
\hline 6 & Membuat video tentang produk, Membuat slide show tentang produk \\
\hline 7 & Mengikuti akun twitter pelanggan \\
\hline 8 & Menambah teman jejaring sosial Mengunjungi halaman situs jejaring sosial orang lain \\
\hline 9 & Meninggalkan komentar di halaman situs jejaring sosial orang lain \\
\hline
\end{tabular}

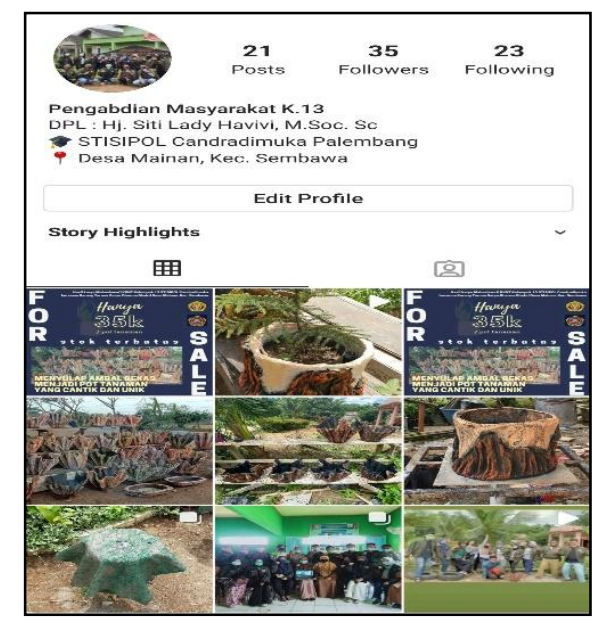

(a)

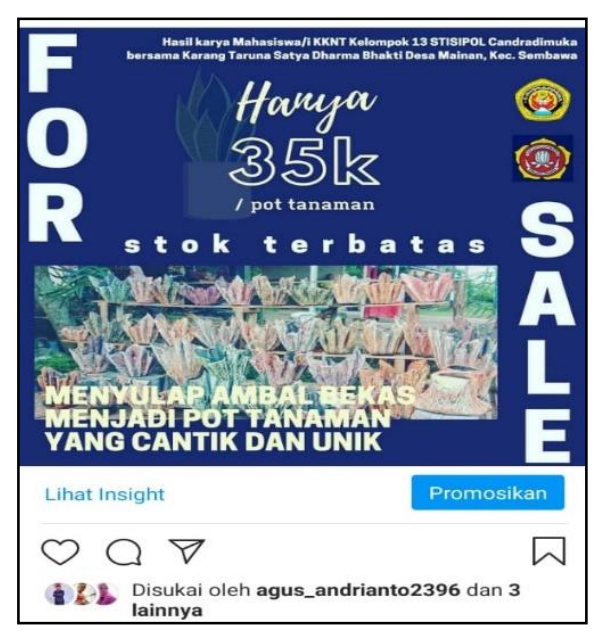

(b)

Gambar 10. (a) dan (b) Pemasaran di Media Sosial 


\section{Kendala yang dihadapi}

Keterbatasan Karang Taruna dalam mengelola manajemen usaha menjadi kendala yang paling besar, dan tentu pada akhirnya berdampak pula pada pemasaran produk. Pembuatan pot tanaman hias ini hanya dilakukan sebagai pekerjaan sampingan di sela-sela kesibukan masing-masing. Sulit bagi mereka untuk dapat mengembangkan usaha pot tanaman hias jika proses produksinya hanya dilakukan pada saat adanya permintaan pasar. Perlu dipahami bahwa kerjasama dengan berbagai pihak harus dilakukan agar dapat membantu dalam pengelolaan manajemen yang memadai, misalnya bekerja sama dengan pemerintah daerah setempat.

Pengoptimalan terhadap penggunaan media sosial juga perlu dilakukan. Karang Taruna hanya menggunakan laman jejaring Facebook sebagai media informasinya untuk berbagi pengalaman, kegiatan serta memasarkan produk pot tanaman hias dan kerajinan tangan. Hal ini dikarenakan kurangnya pengetahuan dan pemahaman bagaimana mengoptimalkan penggunaan media sosial sebagai media pemasaran digital. Menurut Kautsarina (2013), melalui media sosial, kita dapat memasarkan produk dengan cara membagikan informasi kegiatan usaha terkini, membagikan gambar produk pada pasar yang lebih luas, membangun citra produk di dunia maya, menjalin komunikasi dengan calon konsumen, serta memperluas jaringan usaha yang dimiliki.

Melalui kegiatan ini, kemampuan Karang Taruna dalam mengelola usaha pot tanaman hias dapat meningkat. Beberapa hal yang perlu dilakukan ialah membuat rencana kegiatan, mengatur jadwal produksi berkelanjutan, membagi informasi mengenai kegiatan pembuatan pot tanaman hias secara berkala, menggunakan berbagai platform media digital untuk membangun imej, dan memasarkan produk melalui media sosial dengan cara yang kreatif.

Kegiatan pengabdian pada masyarakat yang dilakukan ini sangat bermanfaat dalam meningkatkan pengetahuan anggota Karang Taruna dalam memanfaatkan media sosial sebagai sarana pemasaran produk, sehingga memberikan peluang untuk dapat mengenalkan potensi yang dimiliki Karang Taruna dalam pembuatan pot tanaman hias maupun kerajinan lainnya dalam memanfaatkan barang bekas. Hal ini juga tentu dapat memperluas pasar produk yang dapat berimbas pada peningkatan omset usaha.

\section{Simpulan dan Rekomendasi}

Berdasarkan apa yang telah dipaparkan sebelumnya, maka dapat disimpulkan bahwa kegiatan pengabdian yang dilakukan oleh tim pengabdi adalah untuk mengembangkan potensi yang dimiliki oleh Desa Mainan bersama dengan masyarakatnya sendiri dalam bentuk partisipasi aktif para anggota Karang Taruna.

Berdasarkan kesimpulan di atas, penulis mencoba memberikan saran demi kemajuan Desa Mainan, diantaranya: 
1. Perlunya pembinaan dan pelatihan Digital Marketing kepada Karang Taruna Satya Dharma Bhakti untuk mengembangkan usaha pot tanaman hias dan kerajinan tangan lainnya agar dapat dipasarkan di luar desa, tidak hanya untuk masyarakat sekitar.

2. Perlu diadakannya pelatihan kewirausahaan mandiri agar dapat mendorong masyarakat Desa Mainan untuk lebih kreatif dalam menangkap serta memanfaatkan berbagai peluang usaha yang ada sehingga harapannya dapat berdampak pada kesejahteraan hidup masyarakat Desa Mainan itu sendiri.

3. Perlunya pelatihan Digital Marketing bagi seluruh masyarakat Desa Mainan agar dapat mempercepat peningkatan jumlah UMKM yang masih sangat minim.

4. Hendaknya para pegiat kewirausahaan Karang Taruna tidak hanya terpaku pada pengembangan produk saja namun juga pada pengelolaan manajerial sehingga dapat menjadikan kerajinan tangan ini sebagai usaha yang tahan lama dan berkelanjutan.

\section{Penghargaan}

Kegiatan pengabdian ini tidak akan berjalan dengan optimal tanpa bantuan dari segenap pihak, baik yang terlibat secara aktif maupun pasif dengan caranya masingmasing. Oleh karena itu, tim pengabdian masyarakat mengucapkan terima kasih kepada Yayasan Seni dan Ilmu Pengetahuan (Yasip), Kepala Desa Mainan, dan segenap perangkat Kantor Desa Mainan; Pembina dan para pengurus Karang Taruna Satya Dharma Bhakti, Kelompok Wanita Tani (KWT) Teratai.

\section{Daftar Pustaka}

Barokah, S., Wulandari, OAD., Sari, MT., Yuditama, IF. (2021). Optimalisasi digital marketing melalui Facebook ads di Kelurahan Purwanegara. Jurnal Abdimas BSI. 4 (1). 17-22.

Eko, S. (2002). Pemberdayaan masyarakat desa. Materi diklat pemberdayaan masyarakat desa. Samarinda, Indonesia: Badan Diklat Provinsi Kaltim.

Kartasasmita, G. (1997). Pemberdayaan masyarakat: Konsep pembangunan yang berakar pada masyarakat. Jakarta: Bappenas

Kautsarina. (2013), "Pemasaran Elektronik Melalui Aplikasi Jejaring Sosial", Jurnal Studi Komunikasi dan Media. 17(2). 135-148

Kotler and Keller. 2016. Marketing Management. Pearson: Prentice hall

Purbantara, A dan Mujianto. (2019). Modul KKN Tematik desa membangun: Pemberdayaan masyarakat desa. Jakarta: Kementerian Desa, Pembangunan Daerah Tertinggal dan Transmigrasi Republik Indonesia.

Wardhana, Aditya. (2015). Strategi Digital Marketing dan Implikasinya pada Keunggulan Bersaing UKM di Indonesia 